\title{
Assessment of Knowledge and Practice of Peripheral Intravenous Cannulation in Government Cardiology Hospital in Pakistan
}

\author{
Sumira Keran, Muhammad Hussain, Muhammad Afzal and Professor Dr. Syed Amir Gillani
}

\begin{abstract}
Insertion of peripheral cannula is very commonly used procedure world-wide in hospital settings. Aim of the study is to assess the nurses knowledge about care of intravenous cannulation and to observe their practices during cannula insertion. The current cross sectional study assesses the knowledge and practice of peripheral intravenous cannulation among the nurses of Government hospital, Lahore Pakistan. The data was collected by 170 nurses from the nurses of government hospital Lahore, Pakistan through convinent sampling technique. The results of the study represent that nurses have good understanding about care of cannula but there is lacking in practices.
\end{abstract}

Keywords: Cannula, nurses, practices, peripheral intravenous

DOI: $10.7176 / \mathrm{JHMN} / 84-06$

Publication date: December $31^{\text {st }} 2020$

\section{Introduction}

Insertion of peripheral cannula is very commonly used procedure world-wide in hospital settings. This product is being sold more than billions annually but 30-50\% rate of its failure rate lies (Bertoglio et al., 2017). Peripheral cannula insertion is very easiest, simplest and fastest way to get the access for medication administration, hydration, diagnostic purpose etc. In United Kingdom, one patient from every three patient has peripheral cannula intact (Zhang et al., 2016)

Peripheral cannula insertion is a skill which comes with practice and experience. There are so many complications related to peripheral cannula insertion which can be redness, swelling, pain, itching, extravasation (Sato et al,2016)\%. If cannula is not inserted at right place, into the vein then using such cannula can be result into feeling of pain by the patient, during administration of any medication or fluids it can cause swelling, if chemotherapy or any vesicant drug is being administered then it can cause extravastion too.

Inserting the peripheral cannula is an invasive practice which is performed in emergencies, in hospitalized patients and in radiology department etc (Gargar, Cutamora, \& Abocejo, 2017) Infection related to cannulation is called as phlebitis. There are so many easily occurring complications can be related to this procedure (Arbaee, 2016).

In developed country like United State of America, there are about 80,000 catheter related blood stream infection and 250,000 cases of CRBSIs found in intensive care units per annum (Opilla, 2019)

Failing to pass intravenous cannula can obstruct the patient trust on nurses as it increases their level of apprenhention and agitation. This can be the cause of constriction of peripheral veins, that's why it becomes difficult to complete the job (McNamara, 2018)

When primary nurses or clinical staff fail to pass the peripheral intravenous line then they contact to expert team like anesthetist to come and attempt for cannulation. Anesthetist attempt and get the access of IV cannulation after having many attempts. This time period is very terrible, sad and increase the suffering for the patient (Carr et al., 2016).

Complications related to cannulation can be prevented very easily if health care facilitators like nurses stick to the guidelines of maintaining intravenous cannulation like uses of an aseptic non touch technique, cleaning the patient's skin with approved bactericidal agent and covering the cannulation site with sterile and transparent dressing (Barton, 2018)

In Pakistan a recent studies on peripheral cannulation insertion by (Qamar, Muhammad, Kousar, Waqas, \& Gilani, 2017)reported that nurses have enough knowledge about the steps of peripheral cannula insertion, and they know the care of iv lines but they have no enough resources to follow the steps of cannulation and do the care appropriately.

It is diring need of the current state of health in Pakistan, that nurses should be able to raise the voices on behalf of patient advocacy to prevent the transmission of infection. They should be well knowledgeable and should be equipped with enough resources to provide high quality care of the patient. In addition to this, hand washing is most important way in order to prevent transmission of infection from one person to another person. Washing with soap and water for atleast 40-60 seconds is best recommendation by World Health Organization when hands are visibly dirty or get soiled with blood or body fluids. To break the chain of spread of infection hand washing is more important key. Washing with hand sanitizer is more quick and less time taking process. If hands are visibly dirty, then it can be the reason of transmission of mircro-organisms to others especially to neonates (Isichei-Ukah \& Enabulele, 2018). Selection of hand sanitizer to achieve best result in killing the 
micro-organisms is matter a lot. Select the alcohol based hand sanitizer in order to reduce the spread of infection (Hayat \& Munnawar, 2016).

Furthermore, aim of this study is to assess the nurse's knowledge and practices of peripheral cannula insertion among the public hospital of Lahore, Pakistan.

\section{Scope of the study}

This study helped the nurses to increase their understanding and knowledge about care of peripheral insertion cannula. This study guide the nurses to reduce the infection rate related to peripheral intravenous cannulation insertion and during handling of cannulas. This study help the patients to reduce their sufferings related to IV cannulation and improve the quality care of the hospital.

\section{Literature Review}

Obtaining consent before any procedure is the foremost right of the patient. The professional who is going to do any procedure, is responsible to take the consent from his/her client. According to Joint Commision the person who has constitutional rights to provide care, treatment and all needed services to the clients is responsible to inform to the client about procedural information and what could be the effects and side-effects of the procedure(Farmer \& Lundy, 2017).

For this reason, Nurses has to take initiative steps to actively involve the patient's while giving consent for any procedure either they are agreed for the procedure or they want to refuse it(Felicilda-Reynaldo, 2016).

A study was conducted in Itlay, this study reported the need to level of knowledge of nurses' about some fact-based recommendations peripheral cannula care, it can be direct to less compliance with guiding principle of clinical practice, which can result into harmful effects for the safety of patients. Since then they have established a link between educational level / learning experience and improved understanding score, nurses must strengthen both the role of education and training programs in collaboration with hospital. This study recommends that promote the theory into the practice. Students can acquire core competencies with this aspect become professional nurses. This study offer significant approach for nurse educators which priorities they should plan their academic / teaching program. (Simonetti et al., 2019)

it is suggested to prepare refreshing courses by experienced nurses and suitable teachers for inexperienced nurses. In addition, health care providers are responsible for providing safe and excellent care to patients, so they must be well equipped and properly trained. Adding up, management of government hospital must focus refresher training for senior nurses and registered nurses to comply with practice protocols in order to provide quality care. (Lamsal \& Shrestha, 2019)

Hand hygiene remains important component in reduction of the infection control process before or after doing any health care procedure. It helps to prevent the cross transfer of important viral and multi-resistant bacterial pathogen. Authors suggested that future research must be focused about the optimal implementation methods and monitoring of hand hygiene strategies (Huang, Stewardson, \& Grayson, 2014).

Furthermore, it was suggested that it is domain of administration to provide sufficient resources of hand washing in clinical areas, in the patient's room, in the corridor, at the counters and in the medication room. (Masroor, Doll, Stevens, \& Bearman, 2017).

For difficult cannulation, venous dilation is important aspect which can be achieved by application of torniquete. (Biyik Bayram \& Caliskan, 2016).

\section{Methodology}

Descriptive observational study design will be use in this study. This study will be conducted in inpatients and emergency department of Government Cardiology Hospital. Target Population is nurses working in Government Cardiology Hospital. Inclusion Criteria is that all staff nurses and student nurses who are doing bedside nursing in inpatient units and emergency department who are willing to participate in the research. Exclusion Criteria is that nurses who are performing managerial/administrative task will not part of the study. Nurses who are not willing to participate in the research will not be the part of research. This Study consists of convenience sampling technique of all nurses working in inpatient and emergency department of PIC hospital. Sample size was

According to solvin's formula.

Solvin's formula is $\mathrm{n}=\mathrm{N} /\left(1+\mathrm{Ne}^{2}\right)$ Whereas:

$\mathrm{n}=$ Number of Samples 10

$\mathrm{N}=$ Total Population 260

$\mathrm{E}=$ Margin of Error 0.05\%

Research Instruments are observational checklist and knowledge Questionnaire

Data Collection Techniques are by direct observation during cannulation procedure in Punjab Institute of Cardiology. 
For assessment of nurses knowledge and care of peripheral intravenous cannula, tool was taken by Author Ahmad Niazl Mohm Ghazali and colleagues (Arbaee, 2016).

Data collection about steps of peripheral cannula insertion will be done through valid and reliable tool which is derived from (Dougherty \& Lister, 2015) observational checklist. Data analysis would be done on SPSS 20 version.

Valid and reliable tool which is derived from (Dougherty \& Lister, 2015) observational checklist.

Tools for data collection consist of three parts:

$\mathbf{1}^{\text {st }}$ part consists of characteristics of study participants which include, age, sex, education, year of experience, qualification, working department and any workshops attended related to peripheral intravenous cannulation.

$2^{\text {nd }}$ part consists of knowledge questions related to insertion of peripheral intravenous cannulation.

$3^{\text {rd }}$ part consists of observational checklist of cannulation insertion.

Checklist questionnaire will be used and will be distributed among 170 nurses in PIC

\section{Problem Statement}

Peripheral insertion of cannula is very common procedure in hospital settings of the Pakistan. As per one study in Pakistan, increased infection rate related to this procedure is about 20\% (Ahmed, Khan, \& Beg, 2016). Infection always cost effective and it increased the burden of the hospital and increase the suffering of the patients and families too. To reduce the infection rate among the hospitals, it is important to conduct a study among the public hospitals to control the infection rate and make it strictly implemented to be stick with the guidelines of cannulation insertion while performing this procedure.

\section{Purpose of the study:}

- To assess the nurses Knowledge about care of intravenous cannula

- To determine the nurses Practices related to intravenous cannula insertion

\section{Research Question:}

- To assess the nurses Knowledge about care of intravenous cannula

- To determine the nurses Practices related to intravenous cannula insertion

\begin{tabular}{|c|c|c|c|c|}
\hline S/No. & Knowledge Asessment Questions & YES & NO & I don't know \\
\hline & & Frequency(\%) & Frequency $(\%)$ & Frequency(\%) \\
\hline 1 & $\begin{array}{l}\text { The cannula gauge } 14-20 \mathrm{G} \text { is suitable in adult } \\
\text { patient and } 22-24 \mathrm{G} \text { in paediatric } \\
\text { patient }\end{array}$ & $43(48.8 \%)$ & $86(50.6)$ & $1(0.6)$ \\
\hline 2 & $\begin{array}{l}\text { Veins at dorsal and ventral surface of the upper } \\
\text { extremities are used for IV } \\
\text { cannulation }\end{array}$ & $164(96.5)$ & $6(3.5)$ & $0(0)$ \\
\hline 3 & $\begin{array}{l}\text { Peripheral IV cannula must be removed every } \\
12-72 \mathrm{hr} \text { from insertion time }\end{array}$ & $91(53.5)$ & $75(44.1)$ & $4(2.4)$ \\
\hline 4 & $\begin{array}{l}\text { IV cannula can be used } 48-72 \mathrm{hr} \text { if no signs and } \\
\text { symptoms of complication }\end{array}$ & $153(90)$ & $11(6.5)$ & $6(3.5)$ \\
\hline 5 & Phlebitis is the most identifiable infection & $159(93.5)$ & $11(6.5)$ & $0(0)$ \\
\hline 6 & $\begin{array}{l}\text { The environment sanitation influent the risk of } \\
\text { IV infection }\end{array}$ & $100(58.8)$ & $27(15.9)$ & $43(25.3)$ \\
\hline 7 & $\begin{array}{l}\text { Hand hygiene before IV cannula insertion } \\
\text { prevents infection }\end{array}$ & $75(44.1)$ & $49(28.8)$ & $46(27.1)$ \\
\hline 8 & $\begin{array}{l}\text { Maintaining aseptic technique only during IV } \\
\text { insertion helps to prevent infection }\end{array}$ & $91(53.5)$ & $46(27.1)$ & $33(19.4)$ \\
\hline 9 & $\begin{array}{l}\text { Wearing non-sterile gloves during IV cannula } \\
\text { insertion is advisable }\end{array}$ & 132(77.6) & $38(22.4)$ & $0(0)$ \\
\hline 10 & Skin preparation at insertion site is essential & $170(100)$ & $0(0)$ & $0(0)$ \\
\hline 11 & $\begin{array}{l}\text { Increase attempts for cannulation will increase } \\
\text { the risk of infection }\end{array}$ & $132(77.6)$ & $34(20.0)$ & $4(2.4)$ \\
\hline
\end{tabular}




\begin{tabular}{|c|c|c|c|c|}
\hline S/No. & Knowledge Asessment Questions & YES & NO & I don't know \\
\hline & & Frequency $(\%)$ & Frequency $(\%)$ & Frequency $(\%)$ \\
\hline 12 & $\begin{array}{l}\text { Transparent dressing will help to recognize early } \\
\text { signs and symptoms of infection }\end{array}$ & $170(100)$ & $0(0)$ & $0(0)$ \\
\hline 13 & $\begin{array}{l}\text { Removing extra IV cannula will help to reduce } \\
\text { risk of infection occur }\end{array}$ & $155(91.2)$ & $13(7.6)$ & $2(1.2)$ \\
\hline 14 & $\begin{array}{l}\text { Staphylococcus aureus is the most associated } \\
\text { with cannula tips }\end{array}$ & $24(14.1)$ & $43(25.3)$ & $103(60.6)$ \\
\hline 15 & $\begin{array}{l}\text { Catheter material, size, duration, experience of } \\
\text { the staff etc. influences on risk of } \\
\text { Infection }\end{array}$ & $83(48.8)$ & $87(51.2)$ & $0(0)$ \\
\hline 16 & IV therapy increases risk of IV infection & $147(86.5)$ & $23(13.5)$ & $0(0)$ \\
\hline 17 & $\begin{array}{l}\text { Patient with PIC is on risk of nosocomial } \\
\text { infection }\end{array}$ & $168(98.8)$ & $0(0)$ & $2(1.2)$ \\
\hline 18 & $\begin{array}{l}\text { Patient education on care of IV cannula is } \\
\text { important to reduce risk of infection }\end{array}$ & $170(100)$ & $0(0)$ & $0(0)$ \\
\hline 19 & $\begin{array}{l}\text { I/V cannula should be flushed by inj NS after } \\
\text { any IV Medication }\end{array}$ & $122(71.8)$ & $46(27.1)$ & $2(1.2)$ \\
\hline
\end{tabular}

\begin{tabular}{|c|c|c|c|}
\hline S/NO. & $\begin{array}{c}\text { Checklist for Peripheral Cannula Insertion } \\
\text { Steps }\end{array}$ & $\begin{array}{c}\text { MET } \\
\text { Frequency(\%) }\end{array}$ & $\begin{array}{c}\text { Not Met } \\
\text { Frequency(\%) }\end{array}$ \\
\hline 1 & Explain and discuss the procedure with the patient. & $129(75.9)$ & $41(24.1)$ \\
\hline 2 & $\begin{array}{l}\text { If they require topical local anesthetic, then apply it } \\
\text { to the chosen venepuncture sites for } 30-60 \text { minutes } \\
\text { prior to cannulation. }\end{array}$ & 0 & $170(100)$ \\
\hline 3 & Assemble all the equipment necessary for cannulation. & $139(81.8)$ & $31(18.2)$ \\
\hline \multirow[t]{2}{*}{4} & $\begin{array}{l}\text { Check all packaging before opening and preparing the } \\
\text { equipment to be used. }\end{array}$ & $68(40)$ & $102(60)$ \\
\hline & Procedure & & \\
\hline 5 & $\begin{array}{l}\text { Carefully wash your hands using bactericidal soap and water or } \\
\text { bactericidal alcohol hand-rub and dry. }\end{array}$ & $86(50.6)$ & $84(49.4)$ \\
\hline 6 & $\begin{array}{l}\text { Check your hands for any visibly broken skin, and cover with a } \\
\text { waterproof dressing. }\end{array}$ & $77(45.3)$ & $93(54.7)$ \\
\hline 7 & $\begin{array}{l}\text { In both inpatient and outpatient situations, the correct lighting, } \\
\text { ventilation, privacy and position of the patient must be found. }\end{array}$ & $96(56.5)$ & $74(43.5)$ \\
\hline 8 & Support the chosen limb on a pillow. & $82(48.2)$ & $88(51.8)$ \\
\hline 9 & Apply the tourniquet to the chosen limb. & $100(100)$ & 0 \\
\hline 10 & Assess and select the vein & $100(100)$ & 0 \\
\hline 11 & Release the tourniquet. & $75(44.1)$ & $95(55.9)$ \\
\hline 12 & Select the device based on the vein size. & 164(96.5) & $6(3.5)$ \\
\hline 13 & $\begin{array}{l}\text { Wash hands using bactericidal soap and water or bactericidal } \\
\text { alcohol hand-rub. }\end{array}$ & $52(30.6)$ & $118(69.4)$ \\
\hline 14 & $\begin{array}{l}\text { Open a pack, empty all equipment onto the pack and place a sterile } \\
\text { dressing towel under the patient's arm }\end{array}$ & $0(0)$ & $170(100)$ \\
\hline 15 & Prime the extension set with a syringe of $0.9 \%$ sodium Chloride & $90(52.9)$ & $80(47.1)$ \\
\hline 16 & Reapply the tourniquet. & $0(0)$ & $170(100)$ \\
\hline 17 & $\begin{array}{l}\text { Clean the patient's skin and the selected vein for at least } 30 \\
\text { seconds using } 2 \% \text { chlorhexidine using back-and-forth strokes with } \\
\text { friction and allow to dry. }\end{array}$ & $89(52.4)$ & $81(47.6)$ \\
\hline 18 & Put on gloves. & $91(54.6)$ & $79(45.9)$ \\
\hline 19 & Remove needle guard and inspect the device for any faults & $86(50.6)$ & $84(49.4)$ \\
\hline 20 & $\begin{array}{l}\text { Anchor the vein with the non-dominant hand by applying manual } \\
\text { traction on the skin a few centimeters below the proposed site of } \\
\text { insertion }\end{array}$ & $170(100)$ & $0(0)$ \\
\hline
\end{tabular}




\begin{tabular}{|c|c|c|c|}
\hline S/NO. & $\begin{array}{c}\text { Checklist for Peripheral Cannula Insertion } \\
\text { Steps } \\
\end{array}$ & $\begin{array}{c}\text { MET } \\
\text { Frequency }(\%)\end{array}$ & $\begin{array}{c}\text { Not Met } \\
\text { Frequency }(\%)\end{array}$ \\
\hline 21 & $\begin{array}{l}\text { Holding the cannula in the dominant hand, ensure that it is in the } \\
\text { bevel-up position and place the device directly over the vein; insert } \\
\text { the cannula through the skin at the selected angle according to the } \\
\text { depth of the vein }\end{array}$ & $170(100)$ & 0 \\
\hline 22 & $\begin{array}{l}\text { Wait for the first flashback of blood in the flashback } \\
\text { chamber of the stylet }\end{array}$ & $170(100)$ & 0 \\
\hline 23 & $\begin{array}{l}\text { Level the device by decreasing the angle between the cannula and } \\
\text { the skin. Advance the cannula slightly to ensure entry into the } \\
\text { lumen of the vein. }\end{array}$ & $170(100)$ & 0 \\
\hline 24 & $\begin{array}{l}\text { Withdraw the stylet slightly with the dominant hand and a second } \\
\text { flash-back of blood will be seen along the shaft of the cannula }\end{array}$ & $170(100)$ & 0 \\
\hline 25 & $\begin{array}{l}\text { Maintaining skin traction with the non-dominant hand and using } \\
\text { the dominant hand, slowly advance the cannula off the stylet and } \\
\text { into the vein. }\end{array}$ & $170(100)$ & 0 \\
\hline 26 & Release the tourniquet. To decrease the pressure within the vein. & $170(100)$ & 0 \\
\hline 27 & $\begin{array}{l}\text { Apply digital pressure to the vein above the cannula tip and remove } \\
\text { the stylet }\end{array}$ & $170(100)$ & 0 \\
\hline 28 & $\begin{array}{l}\text { Immediately dispose of the stylet into an appropriate sharps } \\
\text { container }\end{array}$ & $170(100)$ & 0 \\
\hline 29 & $\begin{array}{l}\text { Attach a primed extension set, needleless injection cap or } \\
\text { administration set }\end{array}$ & $170(100)$ & 0 \\
\hline 30 & $\begin{array}{l}\text { Tape/secure the cannula using, for example, the } \\
\text { method illustrated in }\end{array}$ & $170(100)$ & 0 \\
\hline 31 & $\begin{array}{l}\text { Aspirate to check for blood flashback then flush the cannula with } \\
0.9 \% \text { sodium chloride using a pulsatile flush ending with positive } \\
\text { pressure. }\end{array}$ & $95(55.9)$ & $75(44.1)$ \\
\hline 32 & $\begin{array}{l}\text { Observe the site for signs of swelling or leakage and ask the patient } \\
\text { if they are experiencing any discomfort or pain. }\end{array}$ & $170(100)$ & 0 \\
\hline \multirow[t]{2}{*}{33} & $\begin{array}{l}\text { Cover with low-linting swabs or appropriate dressing and bandage } \\
\text { firmly. }\end{array}$ & $170(100)$ & 0 \\
\hline & Post-procedure & & \\
\hline 34 & $\begin{array}{l}\text { Remove gloves and discard waste, making sure it is placed in } \\
\text { appropriate containers. }\end{array}$ & $103(60.6)$ & $67(39.4)$ \\
\hline 35 & $\begin{array}{l}\text { Document date and time of insertion, site and size of cannula, } \\
\text { number of attempts and sign in patient's notes or care plan. }\end{array}$ & $109(64.1)$ & $61(35.1)$ \\
\hline
\end{tabular}

\section{Demographic}

$37.6 \%$ were belongs to $24-28$ years of age group, $31.2 \%$ were from $29-33$ years old and $9.4 \%$ were more than 38 years old. $67.1 \%$ have job experience of 1 -5years, $23.5 \%$ have job experience of $6-10$ years and only $9.4 \%$ have more than 10years job experience. $67.1 \%$ have job experience of $1-5 y e a r s, 23.5 \%$ have job experience of $6-10$ years and only $9.4 \%$ have more than 10years job experience.

\section{Discussion}

All participants were female. (Knowledge questions interpretation) $48.8 \%$ staff nurses reported that $14-20 \mathrm{G}$ Is suitable in adult patient and $22-24 \mathrm{G}$ in pediatric patient while $50.6 \%$ said no and only $0.6 \%$ has no any idea about that. 96.5\% participants said that veins at dorsal and ventral surface of the upper extremities are used for IV cannulation. Whereas $3.5 \%$ said no. $53.5 \%$ participant said that peripheral IV cannula must be removed every $12-72 \mathrm{hrs}$ from insertion time, whereas $44.1 \%$ said no and only $2.4 \%$ participant that don't know about this. $90 \%$ Participant reported that IV cannula can be used 48-72hrs if no signs and symptoms of complication, whereas $6.5 \%$ said no and only $3.5 \%$ has no any information about that. $93.5 \%$ participants reported that phlebitis is the most identifiable infection whereas $6.5 \%$ said no. $58.8 \%$ participant reported that environment sanitation influent the risk of IV infection.15.9\% reported that there is no any risk of IV infection due to environment sanitation and only $25.3 \%$ have no any information about this. $44.1 \%$ reported that hand hygiene before IV cannula insertion prevents infection.28.8 \% reported that hand hygiene before iv cannula insertion do not prevents infection and $27.1 \%$ have no any idea about that. $53.5 \%$ reported that maintaining aseptic technique only during IV insertion helps to prevent infection. $27.1 \%$ reported that maintaining aseptic technique during IV 
insertion does not help to prevent infection and $19.4 \%$ have no any information about that. $77.6 \%$ reported that wearing non-sterile gloves during iv cannula insertion advisable, $22.4 \%$ that wearing non-sterile gloves during IV cannula insertion is not adviseable.

100participants reported that skin preparation at insertion site is essential. $77.6 \%$ reported that increase attempst for cannulation will increase the risk of infection and $20 \%$ reported that increase attempt for cannulation will not increase the risk of infection and only $2.4 \%$ have no any information about that. $100 \%$ participant reported that transparent dressing will help to recognize early signs and symptoms of infection. Majority of participants $91.2 \%$ reported that removing extra IV cannula will help to reduce risk of infection occur, $7.6 \%$ said that removing extra IV cannula will not help to reduce risk of infection occur. Only $1.2 \%$ participants have no any information about that. 14.1\% reported Staphylococcus aureus is the most associated with cannula tips. $25.3 \%$ reported that Staphylococcus aureus is the most associated with cannula tips. Whereas majority of participants $60.6 \%$ has no any information about that. $48.8 \%$ participants reported that Catheter material, size, duration, experience of the staff etc. influences on risk of infection whereas slightly greater percentage 51.2 reported that that Catheter material, size, duration, experience of the staff etc. influences on risk of infection. 86.5\% participant reported that IV therapy increases risk of IV infection. Whereas $13.5 \%$ reported that IV therapy does not increases risk of IV infection. 98.8\% reported that Patient with PIC is on risk of nosocomial infection. Whereas only $1.2 \%$ reported that they have no any information regarding this. $100 \%$ participant reported that patient education on care of IV cannula is important to reduce risk of infection. $71.8 \%$ participant reported I/V cannula should be flushed by inj NS after any IV Medication. 27.1\% reported that I/V cannula should not be flushed by inj NS after any IV Medication.

Observation checklist interpretation:

$75.9 \%$ was used to explain and discuss and procedure with the patient whereas $24.1 \%$ were not $100 \%$ participants do not use topical anesthetic prior to cannulation. $81.8 \%$ assemble all the equipment necessary for cannulation whereas $18.2 \%$ don't assemble it. $40 \%$ participants check all packaging before opening and preparing the equipment to be used whereas $60 \%$ don't do this. $50.6 \%$ participants carefully wash their hands using bactericidal soap and water or use bactericidal alcohol hand-rub and dry whereas $49.4 \%$ don't care for it. 45.3\% participants check their hands for any visibly broken skin, and cover with a waterproof dressing whereas 54.7 don't care of covering their open wounds and inspect their hands. $56.5 \%$ participants take care of patient's privacy and position, ventilation and correct lighting whereas $43.5 \%$ don't care for these aspects. $48.2 \%$ participants support the chosen limb on a pillow whereas $51.8 \%$ don't use pillow. $100 \%$ participants apply the tourniquet to the chosen limb. 100\% participants assess and select the vein. $100 \%$ participants release the tourniquet. $96.5 \%$ participants select the device based on the vein size whereas $3.5 \%$ do it on their own choices. $30.6 \%$ wash hands using bactericidal soap and water or use bactericidal alcohol hand-rub whereas $69.4 \%$ don't wash their hands after selecting the vein. $100 \%$ participants don't use sterile packs for cannulation. $52.9 \%$ participants prime the extension set with a syringe of $0.9 \%$ sodium chloride whereas $47.1 \%$ do not prime. $100 \%$ participants don't re-apply the tourniquet. 52.4\% participants clean the patient's skin and selected vein for $30 \mathrm{sec}$ using $2 \%$ chlorhexidine using back and forth strokes with friction and allow dry whereas $47.6 \%$ don't. $53.5 \%$ participants put on gloves and $45.9 \%$ don't. $100 \%$ participants remove the needle guard but $49.4 \%$ participants don't inspect the device for any faults. 100\% participants anchor the vein with the non-dominant hand by applying manual traction on the skin a few centimeters below the proposed site of insertion. 100\% participants hold the cannula, bevel-up and insert the cannula into the vein. $100 \%$ participants wait for the first flash back of blood. $100 \%$ participants advance the cannula into the vein. $100 \%$ participants withdraw the stylet slightly see a second flash back of blood. $100 \%$ participants maintain skin traction, advance the cannula and off the stylet into the vein. $100 \%$ participant releases the tourniquet. $100 \%$ participants apply digital pressure to the vein above the cannula tip and remove the stylet. $100 \%$ participants immediately dispose of the stylet into an appropriate sharps container. $100 \%$ participants attach a primed extension set. $100 \%$ participants secure the cannula with appropriate method. $55.9 \%$ participants use $0.9 \%$ NaCL to flush the canula whereas $44.1 \%$ don't. $100 \%$ participants observe the site for signs of swelling, discomfort or pain. $100 \%$ participants do the appropriate dressing and bandage firmly. Only $60.6 \%$ participants remove gloves and dispose appropriately whereas $39.4 \%$ don't dispose properly. 64.1\% participants document date and time of insertion, site and size of cannula, number of attempts and sign in patient's notes or care plan whereas $35.9 \%$ don't document all above mention things.

\section{Limitation \&Recommendation:}

This study will be conducted only in Punjab Institue of Cardiology because of shortage of time period. Only quantative study design will be use in this study, whereas for good results and increase the generalizability of study, qualitative study can be used.

One must has to investigate the factors that could be have impact on nurses knowledge and practices. 


\section{Conclusion}

Majority of nurses have good knowledge about care and procedure of cannulation but they don't implement completely due to so many factors. Nurses should be well equipped, knowledgeable and skillful before attempting this procedure.

\section{Reference}

Ahmed, B., Khan, I. M., \& Beg, M. A. (2016). Frequency of Central Venous Catheter Related Infections and their Culture and Sensitivity Pattern. Journal of Islamabad Medical \& Dental College (JIMDC), 5(2), 63-66.

Arbaee, I. (2016). Nurses knowledge and practice towards care and maintenance of. Qualitative Research, 1(3), $385-405$.

Barton, A. (2018). Clinical use of closed-system safety peripheral intravenous cannulas. British Journal of Nursing, 27(8), S22-S27.

Bertoglio, S., van Boxtel, T., Goossens, G. A., Dougherty, L., Furtwangler, R., Lennan, E., . . Stas, M. (2017). Improving outcomes of short peripheral vascular access in oncology and chemotherapy administration: Sage Publications Sage UK: London, England.

Carr, P. J., Rippey, J. C., Cooke, M. L., Bharat, C., Murray, K., Higgins, N. S., . . . Rickard, C. M. (2016). Development of a clinical prediction rule to improve peripheral intravenous cannulae first attempt success in the emergency department and reduce post insertion failure rates: theVascular Access Decisions in the Emergency Room (VADER) study protocol. BMJ open, 6(2), e009196.

Gargar, A. P., Cutamora, J. C., \& Abocejo, F. T. (2017). Phlebitis, Infiltration, and Localized Site Infection Among Patients With Peripheral Intravenous Catheters. European Scientific Journal, 13(18), 148-170.

Hayat, A., \& Munnawar, F. (2016). Antibacterial effectiveness of commercially available hand sanitizers. Int $J$ Biol Biotech, 13(3), 427-431.

Isichei-Ukah, O., \& Enabulele, O. (2018). Prevalence and antimicrobial resistance of Pseudomonas aeruginosa recovered from environmental and clinical sources in Benin City, Nigeria. Ife Journal of Science, 20(3), 547-555.

McNamara, L. (2018). The Royal Marsden Manual of Cancer Nursing Procedures: John Wiley \& Sons.

Opilla, M. (2019). Catheter-Related Complications of Home Parenteral Nutrition Adult Short Bowel Syndrome (pp. 147-163): Elsevier.

Qamar, Z., Muhammad, A., Kousar, R., Waqas, A., \& Gilani, S. A. (2017). Assess nurses knowledge and practice towards care and maintenance of peripheral intravenous cannulation in services hospital Lohore, Pakistan. Saudi J. Med. Pharm. Sci, 3(6B), 608-614.

Zhang, L., Cao, S., Marsh, N., Ray-Barruel, G., Flynn, J., Larsen, E., \& Rickard, C. M. (2016). Infection risks associated with peripheral vascular catheters. Journal of infection prevention, 17(5), 207-213. 